\title{
Selected Reference Books of 1967-68
}

\section{INTRODUCTION}

$\mathrm{T}$

HIS ARTICLE continues the semi-annual series ${ }^{1}$ originally edited by Constance M. Winchell. Although it appears under a byline the list is actually a project of the reference department of the Columbia University libraries, and notes are signed with the initials of the individual staff members. ${ }^{2}$

Since the purpose of the list is to present a selection of recent scholarly and foreign works of interest to reference workers in university libraries it does not pretend to be either well balanced or comprehensive. Code numbers (such as AA71, 1EA29) have been used to refer to titles in the Guide to Reference Books ${ }^{3}$ and its Supplement.

\section{BiBLIOGRAPHY}

British Museum. Dept. of Printed Books. General Catalogue of Printed Books. Tenyear Supplement, 1956-1965. London: Trustees of the British Museum, 1968- . v.1- . \&300 the set.

When complete in fifty volumes, this first decennial supplement will both fill the gap (1956-62) between the "Photolithographic edition" (Guide AA67) and the annual volumes of Additions (1963-65), and cumulate the latter. It thus marks another great stride toward making the published Catalogue available on a fairly current basis

${ }^{1}$ CRL, January and July issues starting January, 1952.

${ }^{2}$ Linda Benson, Rita Keckeissen, Joan Krengel, Evelyn Lauer, Eileen Mcllvaine, Fred Oser, Carole Rinne, Marilyn Schwartz; Law Library, Carol Ann Varela.

${ }^{3}$ Constance M. Winchell, Guide to Reference Books (8th ed.; Chicago: ALA, 1967); Supplement (Chicago: ALA, 1968). in a form conducive to efficient use. Some entries in the supplement are marked with an asterisk to indicate correction of a citation as found in the "Photolithographic edition."-E.S.

Greg, Walter Wilson. A Companion to Arber. Oxford: Clarendon, 1967. 45lp. $£ 5,15 s ., 6 d$.

Subtitle: Being a calendar of documents in Edward Arber's Transcript of the Registers of the Company of Stationers of London 1554-1640, with text and calendar of supplementary documents.

This useful handbook is a chronological calendar of the great number of documents included by Arber as illustrative matter in his extensive, but difficult and unindexed, Transcript (Guide AA497). The new work provides "a more or less connected survey . . . of matters which are scattered in no particular order through Arber's five volumes." (Pref.) In addition, Greg has calendared documents not included by Arber, but drawn principally from the sources he used, and relating to the Stationers Company. These, with the editor's annotations, are cited in full in the second section of the book. Calendar entries include reference to Arber's Transcript by volume and page and, for additional documents, to page in the Companion. A full index adds usefulness. Physically, the book is a good example of Clarendon publishing.-R.K.

Michael, Suzanne P. and Michel, Paul Henri. Répertoire des ouvrages imprimés en langue italienne au XVII ${ }^{\mathrm{e}}$ siècle conservés dans les bibliothèques de France. Paris: Editions du Centre National de la Recherche Scientifique, 1967- . v.1(In progress).

Contents: v.1, A-B. 241p. 38F.

Serving both as a union list and a bibliography for the period, this new reference 
work furnishes locations of Italian imprints in more than fifty French libraries, including the Bibliotheque Nationale. Devoted to works of the Seventeenth century, the Répertoire treats only books, with literary (particularly dramatic) and religious works predominating. Not only bibliographically, but historically and orthographically, the work is highly interesting: one can find out about French predilections for Italian writings, and can view the development of the Italian language in the forms used in the titles. Arrangement is by author; anonymous titles will appear after the entire author section has been published. Somewhat similar to Mazzuchelli's uncompleted Gli scrittori d'Italia . . . (1753-63), but less ambitious in scope, the Michel work gives a brief note on the author, followed by a listing of titles, with collation and additional notes where pertinent. Though not comprehensive, this should prove a valuable bibliographic tool for the period.-M.G.S.

Ogilvy, Jack David Angus. Books Known to the English, 597-1066. Cambridge, Mass.: Mediaeval Academy of America, 1967. 300p. (Mediaeval Academy of America Publication 76) $\$ 7.50$.

A compilation which "even the scholar ... may occasionally find . . . a useful aid to memory" (Foreword), this book assembles a considerable amount of widely scattered material for the student of AngloSaxon England. It lists alphabetically by author the works known or possibly known in England before 1066. Evidence of knowledge and use in England is shown in citations to writings of English authors prior to 1066 ; in each case the year of use or the century is added. Occasionally annotations refer to discussions in scholarly sources. Excluded from this list of books are texts of the Bible and liturgical works. An essay on the history of Anglo-Saxon libraries precedes the body of the book, and a short "subject-matter index" and a manuscript index follow it.-R.K.

\section{LIBRARy SCIENCE}

The New York Times Thesaurus of Descriptors. New York: New York Times Co.,
1968. 2v., loose-leaf. $\$ 225$ (including one year's updating service).

Subtitle: A guide for organizing, cataloguing, indexing and searching collections of information on current events.

"Thesaurus" in the context of this title is defined as "a device for ordering and

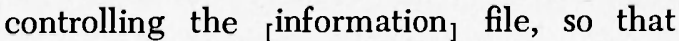
new items may be added consistently to related items, and so that all relevant items are made readily and quickly accessible." (Introd.) Those of us not yet fully computer-oriented may prefer to think of this new work simply as a subject-heading guide designed specifically, as the subtitle indicates, for the newspaper clipping or similar information file related to current events. At any rate the guide emerges as a work generally admirable in the logic of its structure and the precision of its vocabulary. "See" and "See also" references (the latter usually with hierarchical notation as to broader, narrower, or related term), "Refer from" guides, scope notes, and qualifiers all make for clarity and ease of use. While the price is likely to deter purchase by any but those libraries maintaining extensive or specialized clipping and pamphlet files on current events, the Thesaurus will be of great interest to many involved in planning the application of computer technology to library work.-E.S.

\section{Proceedings of Congresses}

Akademiia nauk SSSR. Fundamental'naia biblioteka obshchestvennykh nauk. Nauchnye s'ezdy, konferentsii $i$ soveshchaniia v SSSR, 1954-60; bibliograficheskii ukazatel'. [Moskva ] Nauka, 1966. 2v.

It now appears that this will be a continuing series, the aim of which is to list the Russian language publications of and about scholarly congresses, conferences, and meetings held in the Soviet Union. (An earlier volume of the same title, covering the 1946-53 period, appeared in 1958.) Both the natural and social sciences are represented by entries which are grouped chronologically in a classed arrangement. Alphabetical subject indexes and lists of acronyms and abbreviations for the names of organizations provide keys to the contents of a 
series that scholars and librarians will welcome as a reliable source for verification of hitherto hard-to-identify materials.-E.L.

\section{Directory of Published Proceedings. Series} SSH: Social Sciences/Humanities. v.1, no.1- , Jan. 1968- . White Plains, N.Y.: InterDok Corp., 1968- . Quarterly. $\$ 45$ yr.

\section{At head of title: InterDok.}

Since September, 1965, the InterDok Corporation has issued a Directory of Published Proceedings (Suppl. 1EA29; that series now subtitled "Series SEMT: Science / Engineering / Medicine / Technology") covering conferences, meetings, symposia, and congresses in the whole range of science and technology. This companion series offers a similar listing of published proceedings in the areas of the humanities and social sciences. Entries appear in chronological sequence by conference date, and there are indexes by editor, by place of the conference, and by subject and sponsor. Prices are indicated. An annual cumulated index is promised. Together with Proceedings in Print (Suppl. 1EA30), the InterDok series should greatly simplify the identification and acquisition of often elusive conference publications. - E.S.

\section{Dictionaries}

A Dictionary of Canadianisms on Historical Principles. Produced by the Lexicographical Centre of Canadian English, University of Victoria. Walter S. Avis, ed.-in-chief. Toronto: Gage, 1967. 926p. \$25.

Prepared to appear during the Canadian centennial celebrations, this dictionary seeks to "provide a historical record of words and expressions characteristic of the various spheres of Canadian life during the almost four centuries that English has been used in Canada." (Introd.) The term "Canadianism" is here defined as "a word, expression, or meaning which is native to Canada or which is distinctively characteristic of $\mathrm{Ca}$ nadian usage though not necessarily exclusive to Canada." With the Oxford English Dictionary, A Dictionary of American English, and A Dictionary of Americanisms (Guide AE21, AE80, AE81) as acknowledged models, the entries give: (1) the entry word spelled according to current usage; (2) pronunciation of unfamiliar words in the symbols of the International Phonetic Alphabet; (3) part of speech; (4) etymology; (5) restrictive labels in the following categories: sphere of interest, locale, connotation, and currency; (6) quotations selected to show earliest and, usually, latest evidence, with bibliographical citation for each quotation. The editors' objective has been to produce an interesting as well as informative reference book; for this reason various kinds of information relating to shifts in meaning, complicated etymologies, and other questions requiring more space than is customary have been included. The book succeeds in presenting its material in an interesting and effective manner, and extensive and thorough research seem to underlie the entire project.F.O.

Grzegorczyk, Piotr. Index lexicorum poloniae; bibliografia slowników polskich. Warszawa: Państwowe Wydawiçtwo Naukowe, 1967. 286p. zl.75. Lemmer, Manfred. Deutscher Wortschatz; Bibliographie zur deutschen Lexikologie. Halle: Niemeyer, 1967. 123p. DM6.

These two works are bibliographies of dictionaries, somewhat different in format and content, of the Polish and German languages, respectively. The Lemmer volume is divided into two parts, the first of which selectively cites the most important etymological, modern, regional, technical, and slang dictionaries, as well as collections of quotations and compilations of the vocabulary used by individual German authors. The second part is a bibliography of secondary sources published mainly within the past thirty years and dealing with the problems of German lexicography. Throughout, titles are arranged in rough chronological order under each of the many subject headings. There are no indexes.

In contrast, the Grzegorczyk work has author, title, and subject indexes to its contents which are arranged in five parts: (1) bibliographies of dictionaries, both in monographic and article form, and citations to materials dealing with Polish lexicography; (2) Polish dictionaries, including etymological and dialect dictionaries, and diction- 
aries of synonyms, abbreviations, etc.; (3) bilingual dictionaries; (4) subject dictionaries (monolingual, bilingual, and multilingual); and (5) general encyclopedias. Entries are numbered in one sequence, with citations in chronological order under each heading.-E.L.

Hayakawa, Samuel Ichiyé [et al.] Funk \& Wagnalls Modern Guide to Synonyms and Related Words. New York: Funk \& Wagnalls [1968] 726p. \$8.95.

The collaboration of a noted linguist and an experienced dictionary staff has resulted in the production of a dictionary of synonyms which should be quite useful and adequate for the general inquiry, but which lacks the scope of Webster's Dictionary of Synonyms (Guide AE79). Perhaps the book's principal virtue is its "modernity," for it defines various terms familiar only in the context of the American 'Sixties. As Mr. Hayakawa points out in the introduction, English is richly endowed with resources for distinguishing shades of meaning, and a glance at the pages of this work indicates how fascinating a systematic treatment of these distinctions can be. It is largely a matter of defining the area which the words have in common, and then describing and illustrating the precise connotation of each term. The method of organization used is a series of articles arranged alphabetically by main word. Access to the definitions within the articles is gained by use of an index with a combined total of about five thousand main and secondary words. Within a given set of definitions, individual words are clearly set off in boldface type. In many cases antonyms are given, and often cross references are suggested for words related to, but not synonymous with, the group of words treated in the article. Definitions themselves are supplemented by illustrations of usage in constructed contexts but, unlike Webster's, no examples of actual usage are cited.-F.O.

\section{Periodicals}

Subject Index to New Serial Titles. Ann Arbor, Mich.: Pierian Pr., 1968. 434p. $\$ 29.50$.

Librarians who ordered this work on the assumption that it would prove a kind of cumulation of New Serial Titles-Classed Subject Arrangement (Guide AF100) are apt to be disappointed. This formidablelooking compilation is an index to the Dewey class numbers assigned in New Serial Titles and includes no actual titles. The main section is designated as a "single subject index"; it offers column after column of Dewey class numbers arranged sequentially under brief descriptive subject headings, and gives reference to page and column in the 1950-60 and 1961-65 cumulated editions of New Serial Titles where the full citation for the periodical is to be found. In closely defined areas the index makes for a simple and effective search, but in broad areas only the most diligent are likely to persevere in checking the long columns of page references. A "comparative subject index" provides references to items for which two Dewey numbers were assigned in NST, and there is an alphabetical index of the descriptive subject headings used in the main section, together with the corresponding Dewey class numbers.-E.S.

\section{Newspaper INDEXES}

Le Monde. Index analytique, 1965[Paris, Le Monde, 1967- „ Annual.

With the appearance of this new annual and of the first volume of the index to Le Temps (noted below) the outlook for research involving French newspapers brightens considerably. The index to $L e$ Monde is in the form of a conventional alphabetical subject index, with a number of somewhat unconventional features. Reference is to date of issue only, but the boldface type used for the date makes for easy chronological scanning in long entries. Boldface capitals are used within entries to call attention to names of individual persons, many of whom are not given separate entries within the main body of the index; however, these latter names do appear in an alphabetical sequence of "names cited" at the end of each letter of the alphabet. As in many newspaper and periodical indexes, obituaries, reviews of films, and of stage productions, etc., are brought together under appropriate headings. (Book reviews, with both author and title listing, appear under "Bibliographie.") A chronology of 
events of 1965 precedes the index proper in this first volume.-E.S.

\section{Le Temps. Tables du journal Le Temps.} Paris: Centre National de la Recherche Scientifique, 1966- . v.1- .

At head of title: Institut Français de Presse. Section d'Histoire.

Contents: v.1, 1861-1865. 562p.

This volume indexes the first five years of Le Temps, a newspaper which ran from 1861 to 1942 . Before the project of indexing this publication began, only one major French daily-Le Moniteur-had been indexed, and that only for the revolutionary and Napoleonic periods. In 1958 a scholarly meeting on the history of the French press decided that the lack of a similar tool for the late nineteenth and early twentieth centuries was deplorable. Le Temps, because of its long run, large circulation, and intelligent articles, was chosen for indexing to fill the void.

Short news items and daily or weekly articles of a statistical nature have been omitted, as have articles giving accounts of great events appearing contemporaneous to the events. This latter restriction was enforced because the editors felt that one could easily locate such accounts through the date, and that the citations under the event would be so numerous as to negate the value of the indexing. However, all articles which are not purely news accounts of noteworthy happenings are cited.

Each annual index within the volume is arranged by large geographical area subdivided by such topical headings as general information, political life, economic life, social life, regional life, and cultural life. These broad headings are further divided and redivided, the extent of the subdivision depending upon the importance of the area. Happily, the compilers have provided compensation for this difficult classified arrangement in the form of five-year cumulative proper-name and subject indexes.

The editors, all subject specialists in one or more aspects of the nineteenth century, worked seven years to produce this first volume of what promises to be a very valuable reference tool; we hope that the suc- ceeding volumes will appear more rapidly. $-L . B$.

\section{Government Documents}

Rogers, Frank and Phelps, Rose B. A Guide to British Parliamentary Papers. Urbana: Univ. of Illinois, 1967. 35p. \$1 pa. (Illinois. Univ. Graduate School of Library Service. Occasional papers, 82).

In this publication the authors have condensed three chapters from a projected guide to British documents which will be similar to Boyd and Rips' United States Government Publications (Guide AH7). They first present a brief outline of the parliamentary process, followed by a history of the recording and indexing of what is said in Parliament. Finally, the organization of the sessional papers is examined. The pamphlet is very useful in defining the various series of parliamentary papers, and one of the most helpful sections for a reference librarian is the annotated list of unofficial catalogs and indexes. If the authors had summarized into a similar list the collections of papers and the official indexes to them, the student and librarian would have here a quick guide to these papers.-E.M.

\section{BIOGRAPHY}

Slocum, Robert B. Biographical Dictionaries and Related Works. Detroit: Gale Research [1967] 1056p. \$20.

The eighth edition of the Guide to Reference Books does not have a section headed "Biography-Bibliography," a fact which indicates the gap that Slocum's bibliography is admirably designed to fill. The principal type of work listed herein is the biographical dictionary, although the following types are represented when their contents make it appropriate: bio-bibliographies, collections of epitaphs, genealogical works, dictionaries of anonyms and pseudonyms, historical and specialized subject dictionaries, government and legislative manuals, biographical bibliographies and/or indexes, and selected portrait catalogs. Directories which are merely lists of names and addresses are not included. Basic arrangement is by universal, national (or area), and vocational biography. The work contains about forty-eight 
hundred entries. Full bibliographical descriptions are given except for serial publications with open entries; descriptive notes are added where the compiler felt they were needed. Detailed author, title, and subject indexes are provided. An attempt was made to be representative with respect to all languages and cultures. A few omissions and errors have been noted in the preface, but these, once noted, should not affect the great usefulness of the work, especially in the extended biographical search.-F.O.

Who's Who in Science in Europe: a New Reference Guide to West European Scientists. [Guernsey, Channel Islands Francis Hodgson Ltd. [1967, 3v. 1747p. \&8.

This first attempt to provide a biographical source for the scientists of Western Europe has produced a very useful work of approximately thirty thousand entries. Biographees include scientists in the natural, physical, and medical sciences, technologists, and "those who have interests in the field of research." Scattered entries can also be found for persons in the areas of archaeology and architecture. Each sketch includes the usual brief biographical data, university affiliations, and most recent appointments. While publications are not listed for each individual, a brief description of scientific interests is provided.-J.K.

\section{PhILOSOPHY}

Macquarrie, John, ed. Dictionary of Christian Ethics. Philadelphia: Westminster Pr. [1967] 366p. \$7.50.

Intended to serve as a guide to Christian ethics in the modern world, this one-volume dictionary guides not in the sense of establishing rigid laws of conduct, but rather in the sense of presenting major ethical problems and the leading viewpoints on them. Eighty scholars and theologians have contributed signed articles on basic ethical concepts; philosophical ethical systems; non-Christian ethics; traditional biblical and theological ethics; and ethical problems of the modern world, these supported by background articles drawn from the behavioral sciences. Thus, many of the topics treated here are dealt with in other dictionaries-of philosophy, psychology, and theology-where they are likely to be more fully discussed. Topics and individuals included in this dictionary are presented from the sole point of view of their ethical content or influence. The articles are arranged alphabetically, and cross references are provided. Very short bibliographies are appended to most articles.-L.B.

\section{LITERATURE}

Boyle, Andrew. An Index to the Annuals (1820-1850). Worcester [Eng.] A. Boyle Ltd., 1967. v.1.

Contents: v.1, The authors. 343p. 63s.

Compiled more than thirty years ago (and now published from proofs set before World War II), this work indexes poetry and prose contributions to about two dozen English literary annuals and gift book series of the 1820-1850 period. Listing is alphabetic by author, with contributions to each series grouped thereunder. Reference is to date of the annual, plus page; for poems, both title and opening line are given. There is a separate section for anonyma, giving attributions where possible; another section identifies authors of contributions published as "By the author of. ..." An index of artists is proposed as a second volume.-E.S.

Encyclopedia of World Literature in the 20th Century. Gen. ed., Wolfgang Bernard Fleischmann. New York: F. Ungar, 1967- . v.1- . (In progress).

Contents: v.1, A-Futurism, 425p. \$22.50.

Based on the Lexikon der Weltliteratur in 20. Jahrhundert (Guide BD28), this encyclopedia, alphabetically arranged, is designed primarily for English speaking readers. Signed articles treat of twentieth century authors, genres, literary movements, and surveys of national literatures, all selected for "the needs of those interested in the relationship of Anglo-American letters to other bodies of literature." (Introd.) Each article concludes with a bibliography which usually updates that in the German work. Another feature is the inclusion with the biography of brief quotations of critical material concerning a major author, these 
critical remarks being translated when in a language other than English. The bibliographies, as well as the advantage resulting from bringing together in one place varied information concerning twentieth century literary figures of all countries, make this work very useful for reference.E.M.

Lewanski, Richard Casimir. The Slavic Literatures. New York: New York Public Library and F. Ungar [1967, 630p. $\$ 18.50$. (The literatures of the world in English translation, v.2).

In this volume the compiler has attempted to list all translations of Slavic belles lettres (fiction, poetry, drama, children's literature, and sermons, as well as scholarly, philosophical, political, and journalistic writings of literary merit) which have been separately published or included in anthologies and periodicals up to 1960 . Both the English speaking student and the research worker in any of the Slavic literatures will find this a most useful compilation, since translations, especially of shorter literary pieces, are often extremely difficult to locate. The basic arrangement is by language, with a first section devoted to general anthologies. Each language section also has an initial division for anthologies, followed by an alphabetical author listing with variant editions of a single work arranged in reverse chronological order.

The only real fault to be found with this otherwise distinguished bibliography is the lack of an index of the foreign language titles. The reader may find it difficult to locate a translation if he is familiar only with the vernacular form, for titles appear only in English. Cross references from alternate English titles to a standard version, and all likely variants of an author's name (pseudonyms, nicknames, maiden and married names) are given in the extensive author-title index. Another index of anthologies and their compilers completes this qualitatively excellent and well-organized work.-E.L.

\section{Social Sciences}

International Encyclopedia of the Social Sciences. David L. Sills, ed. [New York
Macmillan Co. and the Free Press [1968] 17 v. $\$ 495$.

A completely new reference work, the long awaited International Encyclopedia of the Social Sciences is intended to complement rather than to supplant its predecessor, the Encyclopaedia of the Social Sciences (Guide CA27). Its purpose, therefore, is to reflect thirty years' growth in fields of the social sciences: anthropology, economics, geography, history, law, political science, psychiatry, psychology, sociology, and statistics. Emphasis is placed upon the analytical and comparative rather than historical and descriptive aspects of topics treated. Biography, represented by four thousand articles in the 1930 encyclopedia, has been de-emphasized in the present work; however, over half of the six hundred biographees here treated were not covered in the earlier set. The new encyclopedia, unlike its predecessor, includes living people-provided they were born before 1890 .

Approximately fifteen hundred scholars from over thirty countries have contributed articles. The alphabetical arrangement of entries is augmented by copious cross-references both within the text and appended to articles; by a detailed index volume; and by grouping under a single heading of several specific articles having in common a general subject matter. In accord with the practice adopted for the previous edition, all articles are signed and accompanied by lengthy bibliographies intended both to document the text and to suggest material for further reading. The usefulness of the 1930 encyclopedia foreshadows the value of this new reference work for any research library.-L.B.

\section{Education}

Altbach, Philip. A Select Bibliography on Students, Politics and Higher Education. Cambridge, Mass.: 1967. 54p. $\$ 2.50$ pa. (Harvard Univ. Center for International Affairs. Occasional papers in international affairs, 16).

This bibliography is intended to facilitate research in the area of student politics and education. In roughly eight hundred listings, the compiler has cited the most im- 
portant items (books, theses, and periodical articles) from the recent literature on the subject. Material is not confined to Englishlanguage publications, but includes works in French, German, and Spanish. Listings are divided into five categories, including students in general, international student politics, foreign students, and student publications. The largest category is devoted to students in particular regions and countries of the world. The bibliography is not annotated, but references considered to be of primary importance have been starred. Although far from exhaustive, the bibliography has already proven invaluable for research in this area of current interest.-J.K.

\section{SocIOLOGY}

Klein, Bernard, and Icolari, Daniel, eds. Reference Encyclopedia of the American Indian. New York: B. Klein [1967, 536p. $\$ 15$.

"Directory" would better describe this work than the "encyclopedia" of its title. It is a compilation of many lists of information sources-government agencies, museums, libraries, reservations, tribal councils, associations, publications-relating to contemporary American Indian affairs. Title of organization, address, director, and sometimes a short annotation are given. Because lists are often closely related, many entries appear in more than one, with duplication of information. What will probably prove the most useful section for reference use is that devoted to biography (about a third of the whole), which contains short "who's who" type sketches of contemporary Indians of professional achievement and of other persons presently active in all phases of American Indian affairs.-R.K.

Ploski, Harry A., and Brown, Roscoe C., comps. The Negro Almanac. New York: Bellwether [1967, 1012p. \$22.

In compiling this reference tool, the editors have attempted to serve the "widest possible audience with an accurate ... welldocumented study of Negro life" (Pref.) in one comprehensive volume. Because it includes such a variety of topics in the social science fields, with a great many at- tractive illustrations and full page portraits, followed by an up-to-date, twenty-page bibliography, this new work should prove one of the most popular of the several recently published reference volumes on the Negro. Of special note for the reference library are sections on significant documents, the Negro press, and national Negro organizations, as well as more general biographical data. Much statistical information is included, some of it nearly compiled, all with sources cited. While emphasis is on United States conditions, Negro life in other parts of the world is also surveyed. Extensive indexing, in addition to the almanac format, makes this a particularly useful tool.-C.R.

\section{LAw}

Association of American Law Schools. Law Books Recommended for Libraries. South Hackensack, N.J.: Fred B. Rothman, 1967- . To be in 6 loose-leaf vols. $\$ 175$.

Although planned as a book-selection guide for law libraries, the annotated subject arrangement of this work makes it a valuable tool for librarians and scholars in other fields as well. Each of the forty-six topics, ranging from accounting to trade regulations, is published as a separate pamphlet, and may be purchased as such. These individual subject lists of works on foreign and common law generally adhere to a standard format; encyclopedias, periodicals, dictionaries, and law reports are included, with the larger portion of each bibliography devoted to selected treatises on the specific subject. The titles included in the lists are considered by law teachers and librarians to be authoritative in their fields, and do not necessarily represent current material. Each title is identified with a symbol to indicate the size of the law library for which it is recommended. Most of the lists were compiled by Miles $\mathrm{O}$. Price, former Columbia University law librarian, and were revised by law faculty and librarians throughout the country; some of the most specialized bibliographies were submitted by experts in the subjects. Upon completion of the final list by December 1968, this cooperative evaluation of the best in the legal literature will be one of 
the most useful tools available for research and for acquisition of law materials. Periodic supplements will be offered.-C.B.V.

\section{Geography}

Documentatio geographica. Geographische Zeitschriften-und Serien-Literatur. Jahresband 1966- . Bad Godesberg: Bundesanstalt für Landeskunde und Raumforschung, 1967- . Annual.

Subtitle also in English, French, Spanish and Russian.

This work represents an initial attempt to establish what will be a continuous documentation service "to promote geographical research and study on national and international levels." (Pref.) This first compilation is divided into title and index volumes, and includes literature references for all geographical journals and periodicals in each country around the world: articles, monographs in yearbooks, research reports, bibliographical reviews, and conference résumés. To meet the demand for up-todate documentation, citations have been adapted to make them retrievable from magnetic tapes for subsequent computer printout. Each citation gives a UDC class number as well as appropriate subject headings, author's name, title, source, place and date of publication. The register volume is divided into indexes by author's name and by subject, and a UDC index. Although the citations are somewhat difficult to interpret initially, the comprehensiveness of the indexing will make this a welcome research tool.-J.K.

\section{Atras}

The Times, London. Times Atlas of the World. Comprehensive edition. Ed. by John Bartholomew. Boston: Houghton Mifflin, 1967. 123 maps on 244p., 272p. $\$ 45$.

According to the editor, this new onevolume edition of the Times Atlas appears in response to continued demand for the five-volume "mid-century edition" (Guide CK224) after a decade in which change has been so rapid as to make reprinting of that work impractical. Thus, inclusion for this more limited edition emphasizes "those features of primary geographical interest where outstanding progress has been made." (Foreword) Exploration of space has brought about significant changes: detailed plates mapping the moon are included, and corrections are made in the dimensions and shape of the earth from new information provided by artificial satellites. The main section of political maps is detailed and up-to-date, and a brief additional section deals with the world's resources and their distribution. Useful reference features include a table of geographical comparisons, an international glossary of geographical terms, and an index-gazetteer of some two hundred thousand place names. Its binding is the work's only serious drawback: plates are sewn through the center rather than guarded as in the previous edition. Thus, double-page maps do not lie flat, and the center sections are somewhat difficult to read.-C.R.

\section{HistoRY}

Roach, John, ed. A Bibliography of Modern History. Cambridge: University Pr., 1968. 1968. 388p. 30s.

Detailed, chapter-by-chapter bibliographies were an outstanding reference feature of the first edition of the Cambridge Modern History (Guide DAI18); the New Cambridge Modern History, however, does not include bibliographies. This volume is intended both as a supplement to the new edition of the History and as a reference work in its own right. By comparison with the earlier bibliographies, it is a very selective list, with relatively few citations to periodical articles. Entries are set forth in three chronological sections (1493-1648; 1648-1793; 1793-1945) with appropriate subdivisions keyed to the chapters of the History. Most of the lists were prepared by contributors to the History volumes and, in general, the cutoff date is 1961. There are some very brief descriptive and evaluative notes, and a subject index.-E.S.

Story, Norah. The Oxford Companion to Canadian History and Literature. Toronto, etc.: Oxford University Pr., 1967. 935p. \$15.

“This Companion is intended to provide a single source in which anyone reading a 
Canadian book in English or French can find an explanation of references that would otherwise be obscure." (Introd.) The majority of entries is biographical, covering both historical and literary figures. Historical entries include articles on political and constitutional issues, important places, and special subjects. There are survey articles on literary genres and other literary topics, tracing Canadian developments in chronological sequence. Numerous cross references are employed to relate entries. A feature of the work is the provision with many entries of bibliographies which contain comments and description of the titles cited. Appendixes list governors, administrators, and prime ministers of New France, British North America, and Canada; and there is a section of historical maps. This latest "Oxford Companion" is the work of an archivist with thirty years' experience in the Public Archives of Canada, and initial examination of the book seems to justify confidence in the comprehensiveness, accuracy, and style normally associated with this established series. $-F . O$.

\section{U.S. Dept. of the Interior. Library. Bio-} graphical and Historical Index of American Indians and Persons Involved in Indian Affairs. Boston: G. K. Hall, 1966. $8 v . \$ 510$.

Developed as a quick reference tool in the Bureau of Indian Affairs and continued in the Department of the Interior library where it is now located, this is an alphabetically arranged subject listing of names of chiefs and other prominent Indians, Indian agents, Bureau of Indian Affairs personnel, and of events and places of importance in the history, social conditions, and biography of the American Indian over the past hundred years. Articles, books, parts of books, even single pages, are cited. Though the scope is said to be wider than departmental collections, no outside locations are indicated.

Because the catalog has had "many contributors and few editors" over a long pe- riod of time, inaccuracies and inconsistencies are to be expected in a virtually unedited photographic reproduction. The reader is warned in the preface that entries are often not in standard bibliographical form, and that alphabetizing is "informal within a single letter." In addition, title pages and spine lettering of four of the volumes are inaccurate regarding contents. However, the student of Indian affairs should find the work useful despite its shortcomings.-R.K.

Writings on British History, 1901-1933; a Bibliography of Books and Articles on the History of Great Britain from around 400 A.D. to 1914, published during the years 1901 to 1933 inclusive. London, J. Cape, 1968- . v.1- . (In progress)

At head of title: Royal Historical Society.

Contents: v.1, Auxiliary sciences and general works; v.2, The Middle Ages, 450-1485; v.3, The Tudor and Stuart periods, 14851714.

These new volumes extend the coverage of Writings on British History (Guide DC128) to books and articles published between 1901 and 1945. The new compilation differs in two major aspects from the earlier volumes of the series. First, publications of learned societies, whether separates or articles, are not included; instead, the reader is referred to such works as C. S. Terry's Catalogue of the Publications of Scottish Historical and Kindred Clubs and Societies (Guide DC170) for coverage of these materials. The second point of change is in the indexing: there is an index of personal and place names only, except when there are numerous entries for the same name, in which case they are broken down by subjects. The compilers have worked more than ten years to provide this single bibliographical guide for writings from a period in which students have previously had to consult a great number of indexes. Volumes IV and V, soon to be published, will cover the periods $1714-1815$ and 1815 1914, respectively.-E.M. 